\title{
STUDI KOMPERATIF KONSEP PENDIDIKAN DALAM PEMIKIRAN TJOKROAMINOTO, KI HADJAR DAN FREIRE DENGAN UNDANG-UNDANG No. 20 TAHUN 2003 TENTANG SISTEM PENDIDIKAN NASIONAL (SISDIKNAS)
}

\author{
Oleh: \\ Abdul Rahman \\ NIM. 1240101534 \\ Universitas Cokroaminoto Yogyakarta
}

Suatu hal yang selalu dibicarakan oleh masyarakat di belahan dunia dan menarik untuk disinggung tidak lain ialah pendidikan. Karena berbicara persoalan ekonomi, politik, sosial, dan budaya semuanya selalu di relasikan dengan pendidikan. Pendidikan merupakan usaha sadar yang dilakukan oleh setiap individu untuk mengembangkan potensi dalam dirinya. Selain untuk mengembangkan potensi peserta didik, dengan pendidikan pula umat manusia mampu menciptakan peradaban baru lewat penemuan alat-alat teknologi dan berbagai macam alat mutakhir lainnya. Sejarah revolusi industri di Inggris, abad ke-18 ditemukannya gildagilda (alat poduksi) merupakan suatu bentuk hasil dari dialegtika ilmu pengetahuan dan perkembangan filsafat Eropa.

Dalam paradigma masyarakat dunia ketiga khususnya Indonesia, sekarang memandang orientasi pendidikan tidak lain hanya untuk bersaing pada dunia kerja dan mendapatkan upah yang besar. Dengan tergabungnya Indonesia dalam Masyarakat Ekonomi Asean (MEA) ditetapkan Januari 2016 lalu, semakin mengaburkan esensi pendidikan. Karena salah satu efek dari disahkannya kebijakan MEA dalam dunia pendidikan yaitu terjadinya liberalisasi pendidikan dan menciptkan generasi-generasi yang siap kerja serta mampu bertarung dalam ranah pasar bebas. Padahal sudah sangat jelas bahwa pendidikan tidak hanya sebatas untuk bersaing pada dunia kerja, melainkan pendidikan harus mampu menjawab persoalan sosial dan ekonomi politik Negara.

Penelitian ini bertujuan untuk mengetahui bagaimanakah relevansi pendidikan Indonesia, jika dibandingkan dengan konsep pendidikan dalam pemikiran Tjokroaminoto, $\mathrm{Ki}$ Hadjar, Freire dan Sisdiknas. Selain itu penelitian tersebut juga bertujuan untuk mengetahui apa sebenarnya esensi dari pendidikan. Dengan menggunakan metode pendekatan historis, sosiologis, deskriptif dan koperatif dihasilkan kesimpulan sebagai berikut: Pertama pendidikan adalah wadah untuk mengkwalitaskan peserta didik, karena dengan pendidikan umat manusia akan terselamatkan dari kemiskinan intelektual dan ekonomi. Kedua orientasi pendidikan bukan hanya untuk bersaing pada dunia kerja, melainkan pendidikan harus menciptakan generasi-generasi krtis, serta peka dengan lingkungan sosialnya. Ketiga Pendidikan yang membebaskan merupakan pendidikan yang diberikan kepada peserta didik sesuai dengan perkembangan dan potensi yang dimiliki oleh peserta didik agar tumbuh berkembang menjadi manusia yang merdeka.

Kat Kunci: Konsep pemikiran, Tjokroaminoto, Ki Hadjar, Freire dan UU 2003 SISDIKNAS

\section{PENDAHULUAN}

Suatu hal yang selalu dibacarakan oleh masyarakat dibelahan dunia dan menarik untuk disinggung tidak lain ialah pendidikan. Karena berbicara persoalan ekonomi, politik, sosial dan budaya semuanya selalu direlasikan dengan pendidikan. Pendidikan dalam sejarah 
kemunculannya sebagai kegiatan untuk mengisi waktu luang masyarakat Yunani pada saat itu. Orang-orang yang mengenyam pendidikan lebih diprioritaskan kepada golongan patriarki, karena dianggap golongan tersebut akan menjadi pemimpin bagi keluarganya. Seiring perkembanganya pendidikan formal/non formal menjadi budaya dalam masyarakat, karena dianggap pendidikan mampu membawa kesejahteraan bagi mereka.

Pendidikan merupakan alat untuk membangun peradaban umat manusia. Suatu peradaban yang maju dengan berbagai pengembangan ilmu pengetahuan dan teknologi mutakhir tak pernah lepas dari peran besar pendidikan. Melalui pendidikan pula manusia memahami nilai-nilai luhur, norma di masyarakat, moral, dan budi pekerti. Pendidikan tidak hanya mengacu pada luasnya pengetahuan yang dimiliki oleh peserta didik. Integrasi antara aspek pengetahuan (kognitif), sikap (afektif), dan keterampilan (psikomotorik) harus dipandang sebagai kesatuan yang utuh dalam membangun karakter diri manusia.

Bapak Pendidikan Nasional,Ki Hadjar Dewantara mengemukakan bahwa pendidikan merupakan proses pembudayaan yakni suatu usaha memberikan nilai-nilai luhur kepada generasi baru dalam masyarakat yang tidak hanya bersifat pemeliharaan tetapi juga dengan maksud memajukan serta mengembangkan kebudayaan menuju arah keluhuran hidup manusia, (Jurnal Pendidikan 2014:4).

Ki Hadjar melanjutkan pendidikan dimulai sejak anak dilahirkan dan berakhir setelah meninggal dunia. Ki Hadjarjuga membedakan antara sistem pengajaran dan pendidikan. Pendidikan dan pengajaran idealnya memerdekakan manusia secara lahiriah dan batiniah selalu relevan untuk segala jaman. Menurutnya pengajaran bersifat memerdekakan manusia dari aspek hidup lahiriah (kemiskinan dan kebodohan). Sedangkan pendidikan lebih memerdekakan manusia dari aspek hidup batin (otonomi berpikir dan mengambil keputusan, martabat dan mentalitas demokratik).

Manusia merdeka itu adalah manusia yang hidupnya secara lahir dan batin tidak tergantung kepada orang lain, akan tetapi ia mampu bersandar dan berdiri di atas kaki sendiri. Artinya sistem pendidikan itu mampu menjadikan setiap individu hidup mandiri dan berani berpikir sendiri. Pengajaran adalah satu bagian dari pendidikan. Artinya pengajaran ialah pendidikan dengan cara memberi ilmu pengetahuan dan memberi kecakapan, pengertian, serta pelatihan kepandaian kepada anak-anak, baik lahir mau maupun batin.

Kemudian para psikologi humanistis seperti Abraham Maslow berpendapat pendidikan yang progresif adalah menyampaikan penataan kembali masyarakat dan bangsa (Yogya: Kanisius 1995:29). Pembangunan sektor pendidikan harus menghasilkan sistem nilai yang mampu mendorong terjadinya perubahan-perubahan positif dalam kehidupan berbangsa dan 
bernegara. Dengan begitu, pendidikan hendaknya dapat menjadi sarana pembangunan manusia yang seutuhnya sebagai subyek yang bermutu dan memberikan transformasi pada perubahan sosial dan masyarakat yang lebih baik, adil, dan sejahtera.

Sedangkan menurut UU. PT. No. 12 Tahun 2012 Bab 1 Ayat 1,Pendidikan adalah usaha sadar dan terencana untuk mewujudkan suasana belajar dan proses pembelajaran agar peserta didik secara aktif dalam mengembangkan potensi dirinya untuk memiliki kekuatan spiritual keagamaan, pengendalian diri, kepribadian, kecerdasan, akhlak mulia, serta keterampilan yang diperlukan dirinya, masyarakat, bangsa dan negara. Sedangkan tujuan pendidikan adalah untuk menyelamatkan umat manusiadari kemiskinan intelektual dan ekonomi.

Dalam paradigm masyarakat dunia ketiga khususnya Indonesia, sekarang memandang orientasi pendidikan tidak lain hanya untuk bersaing pada dunia kerja dan mendapatkan upah yang besar. Dengan tergabungnya Indonesia dalam Masyarakat EkonomiAsean (MEA) ditetapkan Januari 2016 lalu, semakin mengaburkan esensi pendidikan. Karena salah satu efek dari disahkanya kebijakan MEA dalam dunia pendidikan adalah terjadinya liberalisasi pendidikan dan menciptkan generasi-generasi yang siap kerja serta mampu bertarung dalam ranah pasar bebas. Padahal sudah sangat jelas bahwa pendidikan tidak hanya sebatas untuk bersaing pada dunia kerja, melainkan pendidikan harus mampu menjawab persoalan sosial dan ekonomi politik masyarakat.

Bergesernya paradigma masyarakat tentang esensi pendidikan tentunya tidak datang dengan sendirinya, melainkan ada sebuah unsur kesengajaan yang dipropagandakan oleh Negara terhadap basis struktural (masyarakat) sehingga munculkesalahan paradigma masyarakat tentang pendidikan.Sistem ekonomi politik kapitalisme yang menjadi dalang atas semua ini, dengan menggunakan perangkat struktural seperti Negara, aparatus ideologis/media, dan perangkat kebijakan regulasi.Sehingga tidak heran tendensinya output pendidikan Indonesia hanya untuk menopang kerja-kerja laju arus modal kapital. Hal ini kemudian yang mendesain pendidikan diIndonesiasemakin menurun secara kualitas, serta telah mengikis hakekat dari pendidikan itu sendiri.Pendidikan saat ini telah menciptakan gap antara masyarakat, karena realitasnya yang bisa mengenyam sampai PT (Pendidikan Tinggi) hanya orang-orang tergolong ekonomi mapan.

Dalam UU. No. 20 Thn. 2003, pasal 2 dan 3, (SISDIKNAS) mengatur dasar, fungsi dan tujuan pendidikan yaitu pendidikan nasional berdasarkan Pacasila dan UUD NKRI Tahun 1945. Pendidikan nasional berfungsi mengembangkan kemampuan dan membentuk watak serta peradaban bangsa yang bermartabat dalam rangka mencerdaskan kehidupan bangsa, dan bertujuan untuk berkembangnya potensi peserta didik agar menjadi manusia yang beriman, 
dan bertakwa, kepada Tuhan Yang Maha Esa (2003:8). Dalam penjelasan di atas dapat disimpulkan bahwa tujuan dari pendidikan menurut Undang-undang SISDIKNAS adalah untuk mengkualitaskan individu peserta didik agar menjadi manusia yang beriman dan bertakwa kepada Tuhan Yang Maha Esa. Tujuan pendidikan menurut Freire merupakan usaha untuk mengembalikan fungsi pendidikan sebagai alat yang membebaskan manusia dari berbagai bentuk penindasan dan ketertindasan (LP3S, Pendidikan Kaum Tertindas).

Sistem pendidikan dengan segala perangkatnya telah membentuk manusia yang minim apresiasidan kreatifitas manusia untuk berpikir kritis, dalam menganalisis persoalan yang ada. Mahasiswa selalu dijebak pada persoalan tugas, kuliah, dan mengemis nilai pada dosen. Semuanya telah ditelan perangkat sistem pendidikan yang menganut semangat kapital, yang menempatkan mahasiswa sebagai obyek dan guru adalah subject absolut.Ruang-ruang kritis mahasiswadalam berorganisasi sengaja dibatasi lewat regulasi-regulasi kampus agar corak pemikiran mahasiswa ternegasikan dengan kepentingan Negara. Belum lagi diberbagai perguruan tinggibaik negeri maupun swasta yang telah diberikan ruang otonomi kampus, semakin membuat sistem pendidikan Indonesia kurang kontrol oleh Negara.

Otonomi kampus selalu menjadipro kontra bagi publik, karena sebagian mahasiswa menilai bahwa otonomi kampus merupakan sebuah ide berilian yang diterapkan oleh pemerintah karena bagaimanapun setiap kampus juga harus diberikan ruang kebebasan agar bisa lebih berkreatifitas. Namun ternyata ruang otonomi kampus justru menjadi blunder bagi bagi publik, karena ruang otonomi dijadikan sebagai ajang bagi pemilik yayasan untuk mengembangkan usahanya lewat kenaikan biaya pendidikan setiap tahunnya.

Berdasarkan pembahasan diatas perkembangan pendidikan pada fase Neolib sudah kehilangan arah dan tujuannya. Jika pendidikan tidak membicarakan persolan rakyat, maka lebih baik pendidikan itu ditiadakan saja (Tan Malaka). Disini peneliti hendak memfokuskan kajian terhadap pemikiran para ahli seperti HOS Tjokroaminoto, Ki Hadjar Dewantara dan Paulo Freire mengenai pendidikan.

\section{KAJIAN TEORI}

\section{A. Pendidikan Menurut Tjokroaminoto, Ki Hadjar dan Freire}

Pendidikan merupakan usaha sadar yang dilakukan oleh semua umat manusia untuk mengembangkan potensi dalam dirinya masing-masing. Dengan pendidikan pula manusia, mampu memajukan peradaban suprastruktural masyarakat. Sejarah revolusi industri di Inggris, abad ke-18 ditemukanya gilda-gilda (alat poduksi) merupakan suatu bentuk hasil dari dialegtika ilmu pengetahuan dan perkembangan filsafat Eropa. Bangsa Indonesia di bawah 
sistem tanam paksa, pendidikan hanya dijadikan sebagai instrumen untuk melanggengkan kekuasaan imperialisme Belanda.

Atas kondisi tersebut, membuat tokoh-tokoh pergerakan nasional marah karena sikap arogansi imperialisme serta kesewenang-wenangan yang dilakukan oleh imperialisme kepada bangsa pribumi. Sistem diskriminasi antara anak bangsawan dengat rakyat jelata yang cukup tajam, dimana yang mengenyam pendidikan hanyalah para anak bangsawan. Dalam perkembanganya disadari atau tidak orang-orang yang disekolahkan pada saat itu, kemudian menjadi bumerang bagi imperialisme sendiri. Ilmu yang didapatkan dari sekolah Belanda dipakai untuk memberikan penyadaran terhadap pribumi akan pentingnya sebuah arti kemerdekaan.

Di bawah ini akan dijelaskan konsep pendidikan dalam pemikiran tokoh-tokoh yang pernah melibatkan dirinya dalam merebut kemerdekaan bangsa Indonesia di bawah imperialisme Belanda. Tjokroaminoto sebagai pelopor pejuang, guru bangsa, serta penggerak SDI yang kemudian berubah nama menjadi SI, dan Ki Hadjar sebagai Bapak Pendidikan Nasional, orang yang rela melepaskan kasta bangsawanya karena ingin menyatu dengan rakyat. Kemudian tokoh yang terakhir yaitu Bapak Pendidikan Dunia Paulo Freire, dengan gerakan pemberantasan buta huruf di Brazil tahun 1976.

1. Konsep Pendidikan Menurut Pemikiran Tjokroaminoto

Pemikiran Tjokroaminoto mengandung nilai-nilai kebangsaan yang muaranya digunakan untuk melawan penindasan Kolonial Belanda bersama para tokoh perjuangan yang lain. Nilai-nilai kebangsaan ditekankan melalui jalur pendidikan. Pelaksanaan pendidikan dan pengajaran kebangsaan bertujuan untuk menanamkan cita-cita demokrasi sebagai benih dari cita-cita perjuangan dalam usaha mengangkat harkat dan martabat bangsa. Pendidikan juga harus menanamkan prinsip-prinsip keberanian yang bersifat luhur, ikhlas, kesetiaan, dan kecintaan kepada yang benar, menanamkan sifat-sifat budi pekerti yang halus, dan tingkah laku yang menjurus kearah terciptanya sikap sopan santun, serta berperadaban tinggi.

Pendidikan menurut Tjokroaminoto ilmu harus diperoleh dengan akal, tetapi tidak boleh dipisahkan dari pendidikan budi pekerti dan pendidikan rohani. Tjokroaminoto juga menganjurkan dan menitikberatkan pada keseimbangan antara ilmu agama dengan ilmu umum, dan pendidikan harus dapat mempertebal perasaan kebangsaan, bukan sebaliknya mengagung-agungkan budaya asing dan tercabut dari akar budaya sendiri. Pendidikan tersebut harus bertujuan mengangkat derajat maupun martabat dari setiap individu serta berguna bagi bangsa dan Negara. 
Tjokroaminoto secara lebih mendetail menuangkan ide-idenya di dalam artikel yang berjudul Muslim National Onderwijs yaitu: Pelaksanaan pendidikan dan pengajaran harus di tanamkan cita-cita demokrasi sebagai benih dan sumber cita-cita perjuangan dalam usaha mengangkat derajat dan martabat bangsa. Keberanian yang bersifat luhur, ikhlas, kesetiaan, dan kecintaan kepada yang benar harus ditanamkan kepada siswa. Sifat-sifat budi pekerti yang luhur dan tingkah laku yang menjurus kearah terciptanya sikap sopan santun serta berperadaban tinggi harus ditanamkan kepada siswa. Hidup sederhana dan sikap saleh dalam kehidupan beragama, bermasyarakat dan bernegara harus ditanamkan kepada siswa.

Pedidikan dan pengajaran yang erat hubungannya dengan ras kebangsaan (nasionalisme) tidak boleh menyebabkan anak didik terpisah dari adat istiadat dan kehidupan berbahagia dalam pergaulan rumah tangga. Pendidikan dan pengajaran selain harus mampu memperkuat rasa kebangsaan, juga harus mampu meningkatkan kecerdasan bangsa dan memupuk watak yang bertanggung jawab dalam kehidupan berbangsa dan bernegara. Tjokroaminoto melanjutkan pendidikan sebagai paradigma kebebasan dan sebagai alat penyadaran rakyat.

a. Pendidikan Sebagai Paradigma Kebebasan

Bangsa Indonesia telah lama dijajah oleh bangsa Belanda, namun dalam waktu yang cukup lama ini Kolonial Belanda tidak banyak berbuat kebaikan untuk Indonesia khususnya dalam bidang pendidikan. Sistem pendidikan yang dilaksanakan oleh pemerintah Belanda sangat tidak menguntungkan bagi bangsa Indonesia, karena pada dasarnya bertujuan untuk menjadikan warga negara yang mengabdi kepada kepentingan Kolonial, sehingga isi pendidikanya sekedar pengetahuan dan kecakapan yang dapat membantu mempertahankan kekuasaan penjajah.

Disamping itu juga usaha pendidikan yang dilakukan oleh misi Zending ada kecendrungan kearah penetrasi agama sebagai salah satu langkah untuk memperkuat penjajahan Belanda, sehingga dari maksud yang terselubung itu telah menimbulkan rasa tidak senang bangsa Indonesia. Akibatnya mayoritas bangsa Indonesia tidak dapat membaca dan menulis. Oleh karena itu mereka selalu ditemani oleh kebodohan dan keterbelakangan.

Pemerintah Kolonial Belanda selalu berusaha agar dapat hidup langgeng di daerah jajahannya. Untuk mewujudkan keadaan yang demikian itu maka perlu disusun suatu strategi yang matang, karena menurut bangsa Indonesia yakni bangsa Belanda sangat lamban dalam meningkatkan kualitas bangsa Indonesia yang sedang membutuhkan 
pengetahuan. Sehingga sarana tepat yang dapat membebaskannya adalah melalui pendidikan. Pendidikan yang dimaksud adalah pendidikan untuk menciptakan generasi-gerasi kritis agar mampu melepaskan diri dari penjajahan imperialism Belanda.

Pendidikan mampu membebaskan umat manusia dari kungkungan kebodohan yang melilitnya. Namun dalam proses tersebut harus dilandasi oleh nilai-nilai Islam, sehingga tetap dalam lingkaran bingkai Iman dan Islam. Oleh karena itu yang dijadikan sandaran Tjokroaminoto adalah trilogy pendidikan yakni setinggi-tingginya ilmu pengetahuan, sebersih-bersih tauhid dan sepandai-pandai siasat, hanya akan dapat terwujud apabila dilandasi sebersih-bersih tauhid, pendidikan mampu menjadi alat untuk membebaskan diri dari belenggu penjajah. Dengan demikian pendidikan adalah sebagai praktek pembebasan umat manusia dari segala bentuk kedzaliman yang dilakukan oleh orang lain/ kelompok lain.

b. Pendidikan Sebagai Proses Penyadaran

Perjuangan Tjokroaminoto tidak lepas dari problema rakyat terutama umat Islam. Banyak ketimpangan dalam hubungan sosial dalam masyarakat Kolonial sebagai hal yang tidak wajar dan menyinggung rasa harga diri. Seperti cara menghormat kepada Belanda, menyembah, duduk bersila, yang pada saat itu terdapat adanya diskriminasi dalam segala aspek kehidupan bahkan terdapat pula kereta serta kamar tunggu stasiun khusus bagi bumi putera. Dengan menggunakan kekuatan pikiran umat manusia mampu membuka jalan menuju masa depan.

Oleh karenaitu Tjokroaminoto juga berkeinginan mengadakan perbaikan termasuk dalam hal pemerintahan Desa, dengan meningkatkan pendidikan mereka terutama untuk dapat diangkat menjadi kepala Desa sedikit-dikitnya harus lulus sekolah bumi putera kelas dua, dan kepala Desa harus tunduk kepada Dewan Desa yang anggotanya terdiri dari wakil-wakil penduduk Desa. Jelas sekali penekanan konsep yang ingin dikehendaki dalam metode pendidikannya yakni konsep penyadaran pada massa rakyat.

Hal yang menonjol bahwa pendidikan sebagai proses penyadaran (konsistensi), yakni menumbuhkan kesadaran eksistensi potensial manusia yang pada gilirannya dapat menumbuhkan kemampuan kritis, aktif, berintegrasi dengan dunia, mendinamisir, menguasai, dan memanusiakan realitas dengan memberikan arti temporal terhadap ruang geografisnya dan menciptakan kebudayaan sendiri.

Semuanya itu hanya dapat ditumbuh kembangkan apabila manusia telah memiliki kesadaran kritis dan aktif dalam aktifitas sosial. Sebuah konsep pendidikan yang 
realistis, dari kondisi sosial kultural masyarakat yang terbelenggu oleh sistem Kolonial dan tradisi kebangsawanan yang Feodalistik. Tjokroaminoto mampu memberikan alternatife bagi gerakan rakyat dengan pendidikan yang bertumpu pada asas-asas penyadaran akan persamaan hak, rasa kemanusiaan, dan kemerdekaan yang dilandasi oleh ideologi ke Islaman sebagai satu-satunya ideologi pembebasan manusia dari belenggu imperialisme.

\section{Konsep Pendidikan Menurut Pemikiran Ki Hadjar}

Dalam berbagai sumber tulisan tentang pendidikan Ki Hadjar Dewantara, yaitu pendidikan harus dimulai dari persamaan persepsi pemangku pendidikan tentang mendidik itu sendiri. Menurut Ki Hadjar Dewantara mendidik dalam arti yang sesungguhnya adalah proses memanusiakan manusia (humanisasi), yakni pengangkatan manusia ke taraf insani. Di dalam mendidik ada pembelajaran yang merupakan komunikasi eksistensi manusiawi yang otentik kepada manusia, untuk dimiliki, dilanjutkan dan disempurnakan. Jadi sesungguhnya pendidikan adalah usaha bangsa ini membawa manusia Indonesia keluar dari kebodohan, dengan membuka tabir actual-transenden dari sifat alami manusia.

Menurut Ki Hadjar Dewantara tujuan pendidikan adalah penguasaan diri sebab disinilah pendidikan memanusiakan manusia (humanisasi). Penguasaan diri merupakan langkah yang harus dituju untuk tercapainya pendidikan yang memanusiakan manusia. Ketika setiap peserta didik mampu menguasai dirinya, mereka akan mampu juga menentukan sikapnya. Dengan demikian akan tumbuh sikap yang mandiri dan dewasa. Dalam konsep pendidikan Ki Hadjar Dewantara ada dua hal yang harus dibedakan yaitu sistem pengajaran dan pendidikan yang harus bersinergis satu sama lain.

Pengajaran bersifat memerdekakan manusia dari aspek hidup lahiriah (kemiskinan dan kebodohan). Sedangkan, pendidikan lebih memerdekakan manusia dari aspek hidup batin (otonomi berpikir dan mengambil keputusan, martabat, dan mentalitas demokratik). Keinginan yang kuat dari Ki Hadjar Dewantara untuk generasi bangsa ini dan mengingat pentingnya guru yang memiliki kelimpahan mentalitas, moralitas, dan spiritualitas. Bahkan Ki Hadjar sendiri untuk kepentingan mendidik, meneladani, dan pendidikan generasi bangsa ini harus mengubah namanya dari ningratnya sebagai Raden Mas Soewardi Suryaningrat menjadi Ki Hadjar Dewantara.

Bagi Ki Hadjar Dewantara, para guru hendaknya menjadi pribadi yang bermutu dalam kepribadian dan spiritualitas, baru kemudian menyediakan diri untuk menjadi pahlawan dan juga menyiapkan para peserta didik untuk menjadi pembela nusa dan bangsa. Hal utama sebagai pendidik adalah fungsinya sebagai model keteladanan dan sebagai 
fasilitator kelas. Nama Hadjar Dewantara sendiri memiliki makna sebagai guru yang mengajarkan kebaikan, keluhuran, dan keutamaan. Pendidik atau Sang Hadjar adalah seseorang yang memiliki kelebihan di bidang keagamaan dan keimanan, sekaligus masalah-masalah sosial masyarakat.

Menerjemahkan dari konsep pendidikan Ki Hadjar Dewantara tersebut, maka banyak pakar menyepakati bahwa pendidikan di Indonesia haruslah memiliki 3 Landasan filosofis yaitu nasionalistik, universalistik, dan spiritualistik. Nasionalistik maksudnya adalah budaya nasional, bangsa yang merdeka dan independen baik secara politis, ekonomis, maupun spiritual. Universal artinya berdasarkan pada hukum alam (natural law), segala sesuatu merupakan perwujudan dari kehendak Tuhan. Prinsip dasarnya adalah kemerdekaan, merdeka dari segala hambatan cinta, kebahagiaan, keadilan, dan kedamaian tumbuh dalam diri (hati) manusia. Suasana yang dibutuhkan dalam dunia pendidikan adalah suasana yang berprinsip pada kekeluargaan, kebaikan hati, empati, cintakasih dan penghargaan terhadap masing-masing anggotanya.

Pendidikan hendaknya tidak hanya mengembangkan aspek intelektual sebab akan memisahkan dari orang kebanyakan, pendidikan hendaknya memperkaya setiap individu tetapi perbedaan antara masing-masing pribadi harus tetap dipertimbangkan. Pendidikan hendaknya memperkuat rasa percaya diri serta mengembangkan harga diri. Setiap orang harus hidup sederhana dan guru hendaknya rela mengorbankan kepentingan-kepentingan pribadinya demi kebahagiaan para peserta didiknya.

Output pendidikan yang dihasilkan adalah peserta didik yang berkepribadian merdeka, sehat fisik, sehat mental, cerdas, menjadi anggota masyarakat yang berguna, dan bertanggung jawab atas kebahagiaan dirinya dan kesejahteraan orang lain. Dalam pemikiran Ki Hajar Dewantara, metode yang sesuai dengan sistem pendidikan ini adalah sistem among yaitu metode pengajaran dan pendidikan yang berdasarkan pada asih, asah dan asuh. Metode ini secara teknik pengajaran meliputi kepala, hati dan panca indera.

\section{Konsep Pendidikan Menurut Paulo Freire}

Konsep pemikiran Freire tentang pendidikan lebih menonjolkan kemasalahan sosial. Sebagai realitas sosial, ilmu pengetahuan bukan barang yang hanya dimiliki oleh segelintir orang, tetapi kemampuan atau keterampilan untuk melihat dan mengerti kenyataan melalui bahasa yang tepat. Pada tahap ini, secara tidak langsung, teori Freire membongkar positifisme ilmu pengetahuan Barat yang mengasumsikan bahwa pengetahuan adalah suatu yang positif, tetap dan pasti. Freire juga mengakui bahwa pendidikan juga merupakan 
momen kesadaran kritis manusia terhadap berbagai problem sosial yang ada dalam masyarakat.

Freire telah menempatkan manusia dalam berbagai perannya sebagai subyek aktif. Baginya, pendidikan merupakan sebuah proyek percobaan dan agen untuk melakukan perubahan guna membentuk masyarakat baru. Menjadikan pendidikan sebagai proyek percoban, berarti kita berbicara tentang sistem politik kebudayaan (cultural politics) yang menyeluruh dan melampaui batas-batas teoritis dari doktrin politik tertentu, serta berbicara tentang keterkaitan antara teori, kenyataan sosial dan makna emansipasi yang sebenarnya. Sejatinya, politik kebudayaan telah mewakili wacana politik yang mula-mula tujuannya untuk melawan semua bentuk dominasi baik yang bersifat subyektif maupun objektif, serta perjuangan untuk menciptakan pengetahuan, keterampilan dan bentuk-bentuk hubungan sosial yang menjamin adanya emansipasi sosial dan juga emasipasi individu.

Untuk melakukan perubahan pendidikan yang merupakan wadah dan surat perjanjian khusus dengan masyarakat yang memegang dominasi untuk menentukan kehidupan sosial di masa yang akan datang. Bagi Freire, pendidikan juga memuat konsep sekolah. Sekolah yang berarti hanyalah salah satu bagian yang memang cukup penting dimana pendidikan mengambil tempat.

Realitas merupakan medium pembelajaran kritis bagi manusia. Dalam realitas tersebut seluruh potensi manusia berproses sampai membentuk suatu kondisi kepribadian tertentu. Pendidikan tidak bisa dipisahkan dari konteks sosial yang lebih luas dimana ia berada. Bahkan, disadari atau tidak, sebenarnya pendidikan merupakan ajang pertarungan antara berbagai ideologi yang membentuk sosial. Setiap bentuk praktik pendidikan secara politis adalah ruang yang diperebutkan. Jika demikian halnya, pendidikan tidak bisa dipisahkan dari pertarungan antar kepentingan. Pendidikan harus mengambil peranan dalam memproduksi dan menciptakan kehidupan umum, bukan hanya sekedar beradaptasi dengan realitas sosial belaka. Dalam realitas sosial yang sangat kompleks, telah didapati bermacam-macam masalah sosial mulai dari kemiskinan, pengangguran dan keterbelakangan.

Konsep pendidikan yang dihadapkan pada realitas sosial bukan berarti mencetak pesera didik menjadi robot atau mesin-mesin industri yang siap bekerja demi kepentingan kapitalisme global. Bila demikian yang terjadi, pendidikan justru akan menggerus nilainilai kemanusiaan yang semestinya harus di merdekakan. Namun, pendidikan yang dihadapkan realitas sosial adalah pendidikan yang membangun kesadaran kritis peserta didik dalam menghadapi realitas sosial. Kesadaran kritis ini penting agar peserta didik bisa 
menilai secara jernih sekaligus bisa bersikap untuk bisa menyelesaikan masalah yang sedang dihadapinya.

Hal itu dituangkan oleh Freire dalam pemikiranya bahwa pendidikan merupakan alat pembebasan. Pendidikan pembebasan merupakan proses bagi seorang anak manusia untuk menemukan hal yang paling penting dalam kehidupannya, yakni terbebas dari segala hal yang mengekang kemanusiaannya menuju kehidupan yang penuh dengan kebebasan. Bila merujuk pada pemikirannya Freire, pendidikan yang membebaskan adalah pendidikan yang menumbuhkan kesadaran kritis yang mendorong kemampuan peserta didik untuk memiliki kedalaman menafsirkan persoalan nyata dalam kehidupannya. Bila sudah demikian, pendidikan yang membebaskan juga membangun kepercayaan pada diri pesera didik untuk menyikapi keadaan yang terjadi. Oleh karena itu, proses pendidikan dinilai lebih penting dari pada dengan hasilnya.

Dari konsepsi di atas dapat kita simpulkan bahwa pendidikan yang membebaskan terletak pada usaha ke arah rekonsiliasi. Pendidikan seperti itu harus dimulai menghilangkan gap anatara guru dan murid, dimana keduanya merupakan subjek aktif dan memposisikan realitas sebagai objek. Namun sampai saat ini guru masih menjadi momok yang menakutkan bagi peserta didik, hal ini kemudian membuat peserta didik merasa tertekan/ tidak nyaman dalam suasana belajar. Sehingga tidak pernah mencoba untuk menunjukan siapa dirinya, dan berfikir kenapa dia harus belajar.

Metode pengajajaran yang benar yaitu seorang pendidik harus memposisikan peserta didik sebagai phatnership, sehingga tidak melahirkan pendidikan yang kaku dan kontra produktif. Selain itu dalam Kegiatan Belajar Mengajar (KBM) seorang pendidik harus memberikan ruang-ruang demokrasi kepada semua peserta didik. Hal tersebut merupakan salah satu-tahapan awal untuk mewujudkan peserta didik yang kritis dan peka terhadap situasi sosial. Jika model pembelajaran di atas benar-benar diimplemtasikan maka yang terjadi kemudian adalah proses pendidikan yang memanusiakan manusia (humanisasi).

Freire melanjutkan tuajuan utama manusia adalah humanisasi yang ditempuh melalui pendidikan yang membebaskan. Proses untuk menjadi manusia secara penuh akan terjadi apabila manusia berintegrasi dengan dunia. Dalam kedudukannya sebagai subjek, manusia senantiasa mengahadapi berbagai ancaman dan tekanan, namun manusia tetap mampu menciptakan sejarah berkat refleksi kritisnya. Tentunya semua itu terwujud dengan konsepsi pendidikan yang merdeka.

\section{B. Konsep Pendidikan Menurut Undang-Undang SISDIKNAS}


Efek dari krisis ekonomi politik di masa Orde Baru tidak hanya berpengaruh dalam sendi-sendi kehidupan ekonomi politik masyarakat. Namun pada sektor lainpun demikian, seperti sektor pendidikan juga terkena dampak dari krisis kapital Eropa tahun 1998. Situasi krisis itu kemudian memicu masyarakat untuk melakukan protes politik/ unjuk rasa, meminta agar presiden Soeharto mundur dari tapuk kekuasaan. Selain mendesak Soeharto mundur dari singgasana kekuasaan, salah satu tuntutan gerakan rakyat tahun1998, yaitu mendorong untuk melakukan reformasi di bidang pendidikan.

Hal yang sama lahir Forum Rektor Tgl 7 Nopember tahun 1998 yang bertempat di Bandung, juga mendeklarasikan perlunya reformasi budaya, melalui reformasi pendidikan. Tuntutan reformasi itu, dipenuhi oleh DPR-RI, bersama dengan pemerintah, lewat disahkanya Undang-Undang Sisdiknas pada tanggal 11 Juni Tahun 2003. Besar harapan masyarakat sebagai basis struktural bahwa, Sisdiknas mampu menjawab globalisasi dan membawa Indonesia hidup dalam kesetaraan kelas serta sederajat dalam panggung kehidupan internasional dengan bangsa-bangsa maju lainnya. Serta menganggap Sisdiknas mampu mengantarkan rakyat Indonesia menjadi warga dunia modern tanpa kehilangan jati dirinya.

Paska orde baru, sebelum diatur dan dilegalkan Undang-undang Sisdiknas regulasi pendidikan diatur dalam undang-undang No.2 Tahun 1989. Namun banyak pihak menilainya bahwa Undang-undang tersebut tidak sesuai dengan Undang-undang No.22 Tahun 1999 tentang Otonomi Daerah. Atas dasar itulah kemudian disusun Undang-undang yang baru tentang Sistem Pendidikan Nasional, yang meskipun melalui perdebatan yang cukup rumit dan pro kontra dalam tubuh masyarakat, namun akhirnya dapat disahkan menjadi UndangUndang.

Menurut Undang-Undang Sisdiknas, pendidikan adalah usaha sadar dan terencana untuk mewujudkan suasana belajar dan proses pembelajaran agar peserta didik secara aktif mengembangkan potensi dirinya untuk memiliki kekuatan spiritual, pengendalian diri, kepribadian, kecerdasan, akhlak mulia, serta keterampilan yang diperlukan dirinya, masyarakat bangsa dan Negara. Dalam Undang-undang Sisdiknas pendidikan nasional adalah pendidikan yang berdasarkan Pancasila dan Undang-undang Dasar Negara Republik Indonesia Tahun 1945 yang berakar pada nilai-nilai Agama, Kebudayaan Nasional Indonesia, dan tanggap terhadap tuntutan perubahan zaman.

Undang-undang Sisdiknas dan Reformasi dalam dunia pendidikan, disahkan oleh DPR pada tanggal 11 Juni 2003, dan diberlakukan pada tanggal 8 Juli 2003. Dalam Batang Tubuh Undang-Undang tersebut memuat $22 \mathrm{Bab}$, dan 77 Pasal, yang mengatur sistem pendidikan di Indonesia. Secara pointernya dapat dijelaskan sebagai berikut: 


\section{Dasar, Fungsi, dan Tujuan Pendidikan Dalam SISDIKNAS}

Sebagaimana disebutkan dalam Bab II, pasal 1 bahwa: pendidikan nasional berdasarkan Pancasila dan Undang-Undang Dasar Negara Republik Indonesia Tahun 1945. Secara konseptual, dasar pendidikan nasional ini mengandung nilai-nilai yang tidak diragukan lagi kehandalannya, amat ideal dan luhur, dan secara konsensus seluruh bangsa Indonesia sudah menerinya.

Sedangkan fungsi pendidikan nasional yang ditetapkan dalam Pasal 2, yakni: mengembangkan kemampuan dan membentuk watak serta peradaban bangsa yang bermartabat dalam rangka mencerdaskan kehidupan bangsa. Di mana bangsa yang cerdas adalah bangsa yang dibangun atas tiga pilar yaitu: Pertama, memiliki kemampuan dalam menguasai berbagai aspek kehidupan, baik aspek ekonomi, sosial, politik, hukum, ilmu pengetahuan dan teknologi, maupun aspek agama. Kedua, memiliki watak kepribadian yang luhur dan anggun, patriotis dan nasionalis, serta watak bekerja keras dalam memenuhi kebutuhan hidup. Ketiga, memiliki peradaban yang humanis religius, serta kewibawaan yang tinggi, sehingga bangsa-bangsa lain tidak memperlakukan dan mengintervensi bangsa Indonesia.

Selanjutnya, tujuan pendidikan yang ditetapkan dalam pasal tersebut adalah: untuk mengembangkan potensi peserta didik agar menjadi manusia yang beriman dan bertakwa kepada Tuhan Yang Maha Esa, berakhlak mulia, sehat, cakap, kreatif, mandiri, dan menjadi warga negara yang demokratis serta bertanggungjawab.

Konsep ini akan menghasilkan manusia yang sempurna (insan kamil), yakni terbinanya seluruh potensi yang dimiliki baik jasmani, intelektual, emosional, sosial, dan agama. Dengan demikian, ia dapat mengemban tugas hidupnya dengan baik dan penuh tanggung jawab, baik yang berkenaan dengan kepentingan pribadi, masyarakat, bangsa dan Negara.

2. Prinsip Penyelenggaraan Pendidikan

Sebagaimana ditetapkan dalam Bab III, pasal 4: pendidikan diselenggarakan dengan prinsip demokratis, berkeadilan, serta menjunjung tinggi hak asasi manusia, nilai keagamaan, nilai kultural, dan kemajemukan bangsa, prinsip satu kesatuan yang sistemik, prinsip pembudayaan dan pemberdayaan peserta didik, prinsip keteladanan, membangun kemauan, dan mengembangkan kreativitas peserta didik, prinsip pengembangan budaya membaca, menulis dan berhitung, prinsip pemberdayaan semua komponen masyarakat.

Prinsip penyelenggaraan pendidikan yang seperti ini menunjukkan prinsip yang universal, terbuka dan akomodatif dari berbagai aspirasi atau tuntutan masyarakat akan pentingnya pendidikan bagi anak bangsa. Prinsip-prinsip tersebut terletak pada penyelenggaraan 
pendidikan yang demokratis, berkeadilan, desentralisasi, dan menjunjung tinggi hak asasi manusia. Pendidikan yang seperti ini akan memberikan kebebasan dalam berfikir dan berkreasi positif bagi anak didik, serta terbuka bagi masyarakat.

3. Hak dan Kewajiban

Dijelaskan dalam Bab IV, pasal 5: setiap warga negara mempunyai hak yang sama untuk memperoleh pendidikan yang bermutu, dan setiap warga negara bertanggung jawab terhadap keberlangsungan penyelenggaraan pendidikan. Konsep ini lebih menekankan pada pemerataan pendidikan bagi setiap warga negara untuk memperoleh pendidikan yang bermutu. Ada indikasi bahwa permasalahan menonjol yang dihadapi pendidikan nasional, sebagaimana diungkapkan mantan Mendiknas Yahya A. Muhaimin, yaitu: (1) Masih rendahnya pemerataan memperoleh pendidikan, (2) Masih rendahnya mutu dan relevansi pendidikan, dan (3) Masih lemahnya manajemen pendidikan.

Ditetapkannya hak dan kewajiban warga negara tersebut dalam rangka mengantisipasi, mengatasi, dan menuntaskan adanya kesenjangan memperoleh pendidikan yang bermutu. Untuk itu semua warga negara orang tua, masyarakat, dan pemerintah harus dilibatkan secara langsung dalam penyelenggaraan pendidikan. Untuk tujuan itu Undang-Undang Sisdiknas mempersyaratkan adanya badan hukum pendidikan, sebagaimana diamanatkan pasal 53 Undang-undang SISDIKNAS.

\section{Peserta Didik}

Dalam Bab V, pasal 12 bahwa setiap peserta didik pada setiap satuan pendidikan berhak mendapatkan pendidikan agama sesuai dengan agama yang dianutnya dan diajarkan oleh pendidik yang seagama, dan mendapatkan pelayanan pendidikan sesuai dengan bakat, minat, dan kemampuannya. Substansi Bab ini menekankan arti pentingnya pendidikan agama bagi peserta didik yang sesuai dengan agama yang dianutnya, karena bertujuan untuk melindungi akidah agama dalam rangka meningkatkan keimanan dan ketakwaan sesuai dengan agama yang dianutnya. Hal ini sebagai realisasi dari Pancasila, terutama sila pertama: Ketuhanan Yang Maha Esa, dan UUD 1945, Pasal 31 ayat (3): pemerintah mengusahakan dan menyelenggarakan satu sistem pendidikan nasional, yang meningkatkan keimanan dan ketakwaan serta akhlak mulia dalam rangka mencerdaskan kehidupan bangsa, serta untuk mewujudkan tujuan pendidikan yang telah ditetapkan dalam Undang- Undang Sisdiknas.

\section{Standar Nasional Pendidikan}

Sebagaimana ditetapkan dalam Bab IX, pasal 35, menyebutkan: standar nasional pendidikan terdiri atas standar isi, proses, kompetensi lulusan, tenaga kependidikan, sarana 
dan prasarana, pengelolaan, pembiayaan, dan penilaian pendidikan yang harus ditingkatkan secara berencana dan berkala. Konsep ini jelas dan rinci sebagai bahan acuan dalam penyelenggaraan satuan pendidikan termasuk acuan pengembangan program-programnya.

\section{Kurikulum Pendidikan}

Sebagaimana ditetapkan dalam Bab X pasal 36, 37, dan 38 yang intinya dijelaskan: Pengembangan kurikulum dilakukan dengan mengacu standar nasional pendidikan untuk mewujudkan tujuan pendidikan nasional, dengan prinsip diversifikasi sesuai dengan satuan pendidikan, potensi daerah, dan peserta didik. Pengembangan kurikulum yang ditetapkan ini, dalam rangka membekali peserta didik dengan berbagai kemampuan yang sesuai dengan tuntutan jaman.

7. Pendidik dan Tenaga Kependidikan

Tntunya pendidik dan tenaga kependidikan merupakan kunci dalam peningkatan mutu pendidikan dan mereka berada di titik sentral dari setiap usaha reformasi pendidikan yang diarahkan pada perubahan-perubahan kualitatif. Setiap usaha peningkatan mutu pendidikan seperti pembaharuan kurikulum, pengembangan metode-metode mengajar, penyediaan sarana dan prasarana akan berarti manakala melibatkan tenaga pendidik (Guru/ Dosen).

8. Sarana dan Prasarana Pendidikan

Sebagaimana ditetapkan dalam Bab XII pasal 45 ayat 1 dijelaskan bahwa: Setiap satuan pendidikan formal dan nonformal menyediakan sarana dan prasarana yang memenuhi keperluan pendidikan sesuai dengan pertumbuhan dan perkembangan potensi fisik, kecerdasan intelektual, sosial, emosional, dan kejiwaan peserta didik. Pasal ini menekankan pentingnya sarana dan prasarana dalam satuan pendidikan, sebab tanpa didukung adanya sarana dan prasarana yang relevan, maka pendidikan tidak akan berjalan secara efektif.

9. Pendanaan pendidikan

Fokus dari analisis ini lebih diarahkan pada pasal 46 ayat 1 yang menetapkan: pendanaan pendidikan menjadi tanggung jawab bersama antara Pemerintah, Pemerintah Daerah dan masyarakat. Dan pasal 47 ayat 1 dan 2 yaitu: sumber pendanaan pendidikan ditentukan berdasarkan prinsip keadilan, kecukupan, dan berkelanjutan serta Pemerintah Daerah bersama masyarakat menggunakan serta sumber daya yang ada sesuai dengan peraturan perundang-undangan yang belaku.

Pasal ini nampak terlalu politis, artinya keberanian pemerintah dan pemerintah daerah dalam mengalokasikan dana untuk sektor pendidikan selain gaji pendidik dan biaya pendidikan kedinasan adalah minimal 20 persen dari APBN dan APBD, ditambah lagi 
dalam pasal 34 ayat 2, disebutkan bahwa Pemerintah dan Pemerintah Daerah menjamin terselenggaranya wajib belajar minimal pada jenjang pendidikan dasar tanpa memungut biaya. Jika pendidikan murni menjadi tanggung tanggung jawab negara, rakyat Indonesia pasti akan jauh dari yang namanya buta haruf dan semua orang pasti akan mendapat kelas yang sama dalam sruktur masyarakat. Namun, ternyata tanggung jawab pendidikan dalam Undang-undang Sisdiknas bukan murni menjadi tanggung jawab negara, melainkan masyarakat juga terlibat dalam pembiayaan pendidikan demi mejudkan pemerataan pendidikan.

\section{Peran dan Posisi Negara di Sektor Pendidikan}

Berdasarkan amanat pembukaan UUD 1945 bahwa pemeritah Republik Indonesia harus melindungi segenap bangsa Indonesia, dan seluruh tumpah darah Indonesia, dan memajukan kesejahteraan rakyat, mencerdaskan kehidupan bangsa, serta Negara Indonesia harus ikut serta dalam melaksanakan ketertiban dunia. Tujuanya guna rakyat Indonesia menjadi bangsa yang sejahtera secara ekonomi, demokrasi secara politik, adil secara sosial, dan parsisipatif secara budaya. Untuk menjawab semua kebutuhan itu tidak lain sebagai solusi alternatife dengan memberikan fasilitas pendidikan terhadap semua rakyat Indonesia.

Pendidikan merupakan salah satu hak asasi manusia yang tercantum dalam BAB XA tentang Hak Asasi Manusia. Dan juga merupakan salah satu hak dasar warga negara (citizen's right) pada BAB XIII tentang Pendidikan dan Kebudayaan dalam UUD 1945 setelah amandemen. Pasal 28C ayat (1) Setiap orang berhak mengembangkan diri melalui pemenuhan kebutuhan dasarnya, berhak mendapat pendidikan, memperoleh manfaat dari ilmu pengetahuan, teknologi, seni, dan budaya demi meningkatkan kualitas hidupnya dan demi kesejahteraan umat manusia. Hak-hak dasar itu adalah konsekuensi logis dari dasar negara Pancasila yang dianut oleh bangsa Indonesia. Dan sebagai bentuk tanggung jawab negara yaitu harus mewujudkan semua persoalan normatife rakyat tanpa ada diskriminasi.

UUD 1945 Pasal 31 ayat (1): Setiap warga negara berhak mendapat pendidikan/pengajaran. Pasal 31 ayat (2) UUD 1945, mengamanatkan kepada pemerintah Republik Indonesia untuk mengusahakan dan menyelenggarakan satu sistem pengajaran nasional yang diatur dengan Undang-undang. Akan tetapi pada kenyataanya di negara ini masih banyak anak-anak usia sekolah yang tidak bisa memenuhi wajib belajar 9 tahun. Secara garis besar kendala yang menyebabkan itu semua adalah biaya pendidikan di Negara ini yang masih relatife mahal, sehingga banyak masyarakat kalangan menengah kebawah yang tidak bisa melanjutkan pendidikan minimal sampai sembilan (9) Tahun. 
Berdasarkan data UNICEF tahun 2015 lalu, 2,5 juta anak Inodonesia setiap tahunya tidak dapat menikmati pendidikan lanjutan. Diantaranya sebanyak 600 ribu anak usia Sekolah Dasar (SD) dan 1,9 juta anak usia Sekolah Menengah Pertama (SMP). Data statistik tingkat provinsi dan kabupaten menunjukkan bahwa terdapat kelompok anak-anak tertentu yang terkena dampak pailing rentan sebagian besar dari keluarga miskin. Untuk data statistik geografis, tingkat putus sekolah anak SD di desa 3:1 dibandingkan dengan daerah perkotaan. Ini membuktikan lemahnya peran Negara dalam mewujudkan pemerataan pendidikan secara nasional, serta lembaga pendidikan formal cenderung dijadikan sebagai ajang bisnis oleh lembaga pendidikan swasta.

Kemudian dalam perkembanganya, ada sedikit angin segar karena masyarakat tak perlu pusing lagi memikirkan biaya pendidikan. Dana yang sebelumnya dialokasikan untuk membayar iuran sekolah anak, dapat digunakan untuk kebutuhan hidup yang lain. Program dana BOS (Bantuan Operasional Sekolah) yang dimanfaatkan sebaik-baiknya oleh rezim sebagai bentuk pencitraan agar masyarakat selalu melihat sisi baik pemerintah. Hal serupa juga dilakukan oleh Bank Dunia untuk pencitraan eksistensinya. Selaku lembaga yang memberikan pinjaman bagi sebagian pendanaan BOS. (Artikel 2015, memperingati 10 Tahun World Bank memberi BOS).

Pasal 31 ayat 4 Pemerintah memprioritaskan anggaran pendidikan sekurang-kurangnya 20\% dari Anggaran Pendapatan dan Belanja Negara serta dari Anggaran Pendapatan Belanja Daerah untuk memenuhi kebutuhan penyelenggaraan pendidikan nasional. Mencermati pasal 31 ayat 4 ini rupanya wakil rakyat memiliki kesadaran dan keinginan yang kuat untuk merombak anggaran pendidikan yang selama ini berkisar antara 3 sampai dengan 7\% menjadi sedikitnya $20 \%$.

Ada dua hal yang tersirat dalam ayat ini pertama, wakil rakyat menghendaki agar bangsa dan negara yang sedang di landa krisis ini cepat bangkit untuk maju dan mencapai tujuan negara sebagai mana termuat dalam Pembukaan UUD Tahun 1945. Kedua, ada rasa kawatir dengan berlakunya Undang-Undang No.22 Tahun 1999, tentang otonomi daerah yang salah satunya melimpahkan wewenang bidang pendidikan pada setiap daerah masing-masing. Pemerintah masih meragukan apakah mutu pendidikan di daerah nanti lebih baik seperti masa sentralisasi atau sebaliknya. Dengan dasar dan pertimbangan tersebut agar tidak terjadi kesenjangan mutu pendidikan antar daerah maka dalam UUD ditetapkan 20\% dari APBD digunakan untuk kebutuhan penyelenggaraan pendidikan nasional.

Disadari atau tidak, penyebutan anggaran untuk sektor pendidikan minimal $20 \%$ dari RAPBN dan RAPBD itu ada nilai plus minusnya. Plusnya adalah pemerintah pusat/daerah 
menjadikan hal ini sebagai pedoman dalam menyusun anggaran serta masyarakat bisa menjadikannya sebagai patokan dalam melakukan pengawasan terhadap kesungguhan pemerintah. Di tingkat daerah, sekarang banyak pemkab/pemkot yang dengan bangga menyebut angka 20-40\% dari RAPBD-nya untuk pendidikan, tapi sebagian besar anggaran itu digunakan untuk membayar gaji guru/pegawai berstatus PNS. Kalau untuk gaji guru/ pegawai pendidikan saja sudah mengambil 20\% dari RAPBN/ RAPBD, lalu masih adakah biaya untuk pembangunan sarana/prasarana, pemeliharaan, dan penyelenggaraan pendidikan?

Dewasa ini, gaji guru/pegawai pendidikan masih menjadi tanggung jawab pemerintah pusat yang disalurkan melalui Dana Alokasi Umum (DAU) yang diturunkan ke provinsi/ kabupaten/ kota. Otonomi Daerah yang berlaku sekarang masih mengandalkan sebagian besar pembiayaannya pada subsidi pemerintah pusat melalui DAU. Hanya daerah tertentu yang memiliki Pendapatan Asli Daerah (PAD) yang cukup signifikan bagi RAPBD-nya dan sebagian lainnya ditambah lagi dengan pendapatan dari bagi hasil (UU. No. 25 Tahun 1999).

Ada yang mengusulkan agar perhitungan 20\% itu tidak mencakup komponen anggaran untuk gaji sehingga akan tersedia dana yang cukup untuk pengembangan program-program pemerataan kesempatan, peningkatan mutu, dan relevansi pendidikan. Kalau gaji diperhitungkan ke dalam 20\% itu, dikhawatirkan biaya-biaya untuk nongaji bukannya bertambah, malah berkurang dari sebelum ada amandemen ini. Akan tetapi, tidak memasukkan gaji dalam perhitungan anggaran pendidikan juga bisa dikatakan menyalahi prinsip pembiayaan pendidikan yang selalu memasukkan gaji sebagai komponen inti dalam pembiayaan pendidikan. Di situlah letak plus-minus dan dilema pencantuman angka $20 \%$ dalam RAPBN dan kelihatannya hal ini masih akan mengundang perdebatan panjang.

Salah satu tujuan dan cita-cita bangsa Indonesia adalah mencerdaskan kehidupan bangsa yang tertuang dalam Pembukaan UUD 1945 dan Pasal 31 UUD 1945. Berbagai upaya telah dilakukan untuk mencapai tujuan tersebut, termasuk mengamandemen UUD 1945. Setiap upaya tersebut dimaksud untuk memajukan pendidikan di Indonesia. Kualitas pendidikan di Indonesia memang masih sangat rendah bila di bandingkan dengan kualitas pendidikan di negara-negara lain.

Dalam hemat penyusun yang menjadi penyebab utamanya yaitu efektifitas pengawalan anggaran 20\% pendidikan secara nasional belum maksimal, minimnya keseriusan pemerintah dalam mengkualitaskan sistem pendidikan nasional dan masih banyak praktek kapitalisasi pendidikan di berbagai daerah. Adapun solusi yang dapat diberikan dari permasalahan di atas antara lain dengan mengubah sistem-sistem sosial yang berkaitan dengan sistem pendidikan, 
dan meningkatkan kualitas guru serta tujuan pendidikan nasional harus mencapai ranah kognitif, afektif, dan psikomotorik.

Kalau dicermat secara kritis tentang pembiayaan pendidikan antara UUD 1945 dan Undang-undang Sisdiknas ada tumpang tindih. Misalkan, Dalam UUD 1945 menegaskan pendidikan secara absolut merupakan tanggung jawab negara, namun pada Undang-undang Sisdiknas menyebutkan pembiayaan pendidikan juga harus ada kontirbusi dari rakyat. Belum lagi sekarang pembiayaan pendidikan yang semakin tahun semakin mahal, terbukti dalam data penelitian UNSECO, setiap tahun angka putus sekolah yang tidak bisa melanjutkan pada jenjang SLTP dan SMA setiap tahunya 2,5 juta jiwa.

Akibat dari pendidikan yang semakin mahal dan minimnya peran negara, membuat pendidikan Indonesia bukan lagi menjadi konsumsi semua rakyat/mayoritas Indonesia, justu sebaliknya yaitu orang-orang yang bisa mengenyam pendidikan hanyalah yang ekonomi berkecukupan. Kondisi tersebut berefek terhadap implementasi pendidikan, dengan lebih mementingkan hasil, bukan pada substasi pendidikan. Sehingga dalam prakteknya, pendidikan sekarang hanya dijadikan sebagai legitimasi negara yang merupakan kepanjangan tangan dari orang-orang yang memiliki kepentingan kelompok.

UUD 1945 pada esensinya menyatakan bahwa pendidikan nasional bukan bidang usaha jasa untuk menghasilkan tenaga kerja terdidik, yang satu kategori dengan industri pertambangan, perdagangan, jasa perbankan dan keuangan serta jasa-jasa lainnya. Melainkan pendidikan merupakan upaya sosial, politik dan kultural untuk mencerdaskan kehidupan bangsa. Pendidikan sebagai alat untuk mensejahterakan rakyat, dan manakala kekayaan intelektual dimiliki oleh kelompok minoritas, maka disitulah awal dari proses penindasan. Pendidikan juga harus membicarakan persoalan sosial masyarakat, serta memperjelas peran dan posisi negara terhadap pembiayaan pendidikan seperti yang sudah ditegaskan dalam UUD 1945.

\section{METODE}

\section{A. Jenis penelitian}

Penelitian ini merupakan studi pustaka (library research), yaitu penelitian yang dilakukan dengan menghimpun data dari berbagai sumber seperti buku, ensiklopedi, jurnal, majalah, internet, surat kabar dan lain-lain. Penelitian ini bermaksud menjelaskan pemikiran HOS Tjokroaminoto, KI Hadjar Dewantara dan Paulo Freire dengan menggunakan metode penelitian kualitatif.

B. Sumber Data 
Sumber data penelitian ini menggunakan Data Sekunder. Data Sekunder yang dimaksud adalah karya-karya yang dikarang/ditulis lansung oleh HOS Tjokroaminoto, Ki Hadjar Dewantara, dan Paulo Freire atau karya sudah diterjemahkan kedalam bahasa Indonesia, maupun kutipan-kutipan sumber lain yang memuat pemikiran Tjokroaminoto, Ki Hadjar dan Paulo Freire seperti: 1. Paulo Freire, Pendidikan Kaum Tertindas, 2. KI Hajar Dewantra, Novel Sang Guru dan 3. HOS Tjokroaminoto, Guru Bangsa

C. Pengumpulan Data

Metode pengumpulan data dalam penelitian ini memakai metode dokumentasi, yaitu mengumpulkan data dari literatur berupa arsip-arsip, buku-buku, dan data-data sekunder. Setelah terkumpul, mulai mencari key word (kata kunci) untuk memudahkan penelitian, kemudian dilakukan klasifikasi dan mengurutkan sesuai dengan pokok bahasan yang telah ditentukan. Berikut ini adalah (keyword-nya). 1. Pendidikan, 2. Tujuan Pendidikan, 3. Relevansi sistem pendidikan nasional dengan dengan pemikiran Tjokroaminoto, Ki Hadjar Dewantara dan Paulo Freire

D. Analisis Data

Adapun metode yang digunakan dalam menganalisis data penelitian adalah:

1. Pendekatan historis digunakan dalam rangka merunut aspek kesejarahan yang melatarbelakangi kehidupan Tokoh yang dikaji beserta gagasan-gagasanya.

2. Pendekatan sosiologis digunakan untuk menyelusuri pemikiran HOS Tjokroaminoto, Ki Hadjar Dewantara, dan Paulo Freire mengenai konsep pendidikan yang membebaskan. Pendekatan ini dilakukan karena ke-3 tokoh tersebut merupakan tokoh-tokoh yang sangat terkemuka difasenya dan sampai sekarang nama mereka selalu disinggung dalam kajian-kajian kritis.

3. Metode deskriptif, yakni upaya penulis untuk membahas penelitian ini secara sistematis dan terperinci terhadap tema dari aspek-aspek yang dimaksud dalam pemikiran HOS Tjokroaminoto, Ki Hadjar Dewantara, dan Paulo Freire.

4. Penelitian ini juga menggunakan metode komperatif, yaitu menyelami ungkapanungkapan HOS Tjokroaminoto, Ki Hadjar Dewantara, dan Paulo Freire. Serta konsepkonsep yang berkaitan dengan pendidikan, untuk mengungkap esensi pendidikan yang sebenarnya.

5. Dengan metode analisis peneliti akan melakukan pemeriksaan secara konseptual dan makna yang terkandung dalam ungkapan-ungkapan atau argumen yang digunakan HOS Tjokroaminoto, Ki Hadjar Dewantara, dan Paulo Freire sehingga dapat memperoleh substansi makna yang dimaksud dari pandangan tersebut. 


\section{PEMBAHASAN}

1. H.O.S. Tjokroaminoto

Raden Mas Haji Oemar Said Tjokroaminoto atau yang kemudian dikenal dengan HOS Tjokroaminoto merupakan salah satu tokoh pergerakan Indonesia awal abad-20. Tokoh yang lekat dengan Islam dan Sosialis ini lahir di Bakur Madiun, pada tanggal 16 Agustus 1883, dan meninggal di Surabaya pada 17 Desember 1934 dan dimakamkan di TMP Pekuncen Yogyakarta pada usia 52 tahun. Tjokroaminoto merupakan anak kedua dari 12 bersaudara dari ayah bernama R.M. Cokroamiseno, salah seorang pejabat pemerintahan pada saat itu. Tjokroaminoto terlahir dari keluarga berada dan terpandang, dimana garis ayah masih merupakan keturunan kiai yang sangat dihormati oleh masyarakat. Semantara ibunya masih keturunan bangsawan Keraton Surakarta. Dari kecil kehidupanya benar-benar dalam kehidupan islami, walaupun akhirnya pendidikan formal yang ditempuhnya adalah pendidikan Barat. Setelah memasuki dinia pendidikan, ketajaman pikirannya sudah ada ketika ia tidak senang melihat hal-hal yang berlawanan dengan pikirannya.

Sejak belajar di OSVIA (sekolah calon pegawai pemerintah) pemikiran-pemikiran Tjokroaminoto makin berkembang seiring dengan pengetahuan yang dimiliki serta didorong oleh perhatianya terhadap kondisi masyarakat waktu itu. Ketajaman pikiranya dapat dilihat dari keterampilanya dalam bidang karang-mengarang sehingga sebagian surat kabar memuat karyanya. Pemikiran dan perhatiannya banyak mengarah pada soal-soal masyarakat dan kerakyatan. Hal itu tampak dalam tulisan-tulisannya yang selalu mempropagandakan bagaimana usaha membongkar kerusakan-kerusakan dalam masyarakat kemudian memperbaikinya. Selesai dari OSVIA, tahun 1902 sampai 1905 Tjokroaminoto menjadi juru tulis patih di Ngawi Jawa Timur, kemudian menjadi patih utama pada seorang bupati. Pada bulan September, 1905 Tjokroaminoto minta berhenti dari jabatan. Alasannya merasa tidak senang dengan kehidupan kepegawaian yang terus menerus berjongkok dan menyembah kepada atasan. Tjokroaminoto kemudian menikahi Soeharsikin, putri patih Mangoensoemo yang saat itu menjadi wakil Bupati Ponorogo.

Kemudian tepatnya bulan Mei 1912, dan selanjutnya Tjokroaminoto bekerja pada sebuah biro tekhnik di Surabaya. Dalam periode inilah Tjokroaminoto berhubungan dengan beberapa wakil Sarikat Dagangn Islam (SDI) Surakarta yang sengaja mendatanginya. Kontrakannya yang masih berjalan dengan perusahaan ini ditebus oleh pimpinan SDI yaitu Haji Samanhudi, agar Tjokroaminoto dapat memberikan seluruh tenaga dan pikirannya pada perkumpualan yang baru itu. Tjokroaminoto juga diminta untuk menyusun Anggaran Dasar SDI dan duduk 
sebagai posisi komisaris organisasi. Perjalanan SDI tidak bertahan lama, karena setelah itu SDI berubah menjadi SI di bawah kepemiminanan Tjokroaminoto dengan tujuan organisasi tersebut menjadi wadah bagi perjuangan umat Islam.

2. Ki Hadjar Dewantara

Ki Hadjar Dewantara Lahir di Yogyakarta pada tanggal 2 Mei 1889. Terlahir dengan nama Raden Mas Soewardi Soeryaningrat. Ki Hadjar berasal dari lingkungan keluarga kraton Yogyakarta. Raden Mas Soewardi Soeryaningrat, saat genap berusia 40 tahun menurut hitungan Tahun Jawa berganti nama menjadi Ki Hadjar Dewantara. Semenjak saat itu, Ki Hadjar tidak lagi menggunakan gelar kebangsawanan di depan namanya. Hal ini dimaksudkan supaya Ki Hadjar dapat bebas dekat dengan rakyat, baik secara fisik maupun hatinya.

Perjalanan hidupnya benar-benar diwarnai perjuangan dan pengabdian demi kepentingan bangsanya. Ki Hadjar menyelesaikan Sekolah Dasar di ELS (Sekolah Dasar Belanda) Kemudian sempat melanjut ke STOVIA (Sekolah Dokter Bumiputera), tapi tidak sampai tamat karena sakit. Kemudian Ki Hadjar bekerja sebagai wartawan di beberapa surat kabar antara lain Sedyotomo, Midden Java, De Express, Oetoesan Hindia, Kaoem Moeda, Tjahaja Timoer dan Poesara. Pada masanya, Ki Hadjar tergolong penulis handal. Tulisan-tulisannya sangat komunikatif, tajam dan patriotik sehingga mampu membangkitkan semangat anti kolonial bagi pembacanya. Selain ulet sebagai seorang wartawan muda, ia juga aktif dalam organisasi sosial dan politik.

Pada tahun 1908, Ki Hadjar aktif di seksi propaganda Boedi Oetomo untuk mensosialisasikan dan menggugah kesadaran masyarakat Indonesia pada waktu itu, mengenai pentingnya persatuan dan kesatuan dalam berbangsa dan bernegara. Kemudian, bersama Douwes Dekker (Dr. Danudirdja Setyabudhi) dan Dr. Cipto Mangoenkoesoemo, Ki Hadjar mendirikan Indische Partij yaitu partai politik pertama yang beraliran nasionalisme Indonesia pada tanggal 25 Desember, 1912 yang bertujuan mencapai Indonesia merdeka.

Organisasi ini dianggap dapat membangkitkan rasa nasionalisme rakyat dan menggerakan kesatuan untuk menentang pemerintah kolonial Belanda. Ki Hadjar melancarkan kritik terhadap Pemerintah Belanda yang bermaksud merayakan seratus tahun bebasnya negeri Belanda dari penjajahan Prancis dengan menarik uang dari rakyat jajahannya untuk membiayai pesta perayaan tersebut. Sehubungan dengan rencana perayaan itu, Ki Hadjar mengkritik lewat tulisan berjudul Als Ik Eens Nederlander Was (seandainya aku seorang Belanda). Akibat karangannya yang menghina itu, pemerintah kolonial Belanda menjatuhkan hukuman tanpa proses pengadilan, berupa hukuman internering (hukum buang) di Belanda. 
Pasca pembuangan dari Belanda, di tanah Nusantara Ki Hadjar mencurahkan perhatian di bidang pendidikan sebagai bagian dari alat perjuangan meraih kemerdekaan. Ki Hadjar mendirikan sebuah Perguruan Nasional Taman Siswa pada 3 Juli 1922. Perguruan ini sangat menekankan pendidikan rasa kebangsaan kepada peserta didik agar mereka mencintai bangsa dan tanah air dan berjuang untuk memperoleh kemerdekaan. Selain keseriusannya mencurahkan perhatian dalam dunia pendidikan di Taman Siswa, Ki Hadjar juga tetap rajin menulis.

3. Paulo Freire

Paulo Freire lahir pada 19 September 1921 di Recife, Pernambuco, daerah Timur Laut Brazil. Ayahnya bernama Joaquim Temistocles Freire, berprofesi sebagai polisi militer di Pernambuco yang berasal dari Rio Grande de Norte. Ayahnya adalah seorang pengikut aliran kebatinan, tanpa menjadi anggota dari agama resmi, baik budi, cakap, dan sangat mencintai Paulo Freire. Ibunya bernama Edeltrus Neves Freire, berasal dari Pernambuco dan beragama Katolik. Sejak kecil Paulo Freire dipaksa untuk mengetahui realitas secara langsung, sebagaimana getirnya kemiskinan dan kelaparan yang terjadi pada masa depresi besar di tahun 1929 ketika krisis ekonomi di Amerika Serikat yang mulai mempengaruhi Negara Brazil. Dari latar belakang keluarga kelas menengah, Paulo Freire menyadari bahwa dirinya sedang bersentuhan langsung dengan kemiskinan dan kelaparan, itulah yang membangun semangatnya dalam membangunkan masyarakat miskin dari ketertindasan.

Masa mudanya Paulo Freire ketika berumur 20 tahun sudah tertarik dengan praktikpraktik kependidikan. Dalam usia yang cukup belia, Paulo Freire pernah menjadi guru Sekolah Menengah Atas (SMA), yang dalam pengajaranya menggunakan bahasa Portugis. Dan ditahun 1943 Paulo Freire belajar hukum di Universitas Recife. Meski menjadi mahasiswa di bidang hukum, Paulo Freire juga tertarik untuk mempelajari mengenai linguistik, filologi dan filsafat bahasa. Pemikirannya mengenai filsafat pendidikan telah diungkapkan pertama kali pada tahun 1959, dalam desertasi doktornya di Universitas Recife.

Kemudian pada tahun 1961, Paulo Freire diangkat sebagai direktur dari Departemen Kebudayaan Ekstensi Universitas Recife. Pada tahun 1962, Paulo Freire memiliki kesempatan pertama untuk aplikasi yang signifikan dari teori-teorinya, ketika 300 petani tebu diajarkan untuk membaca dan menulis hanya dalam 45 hari. Menanggapi eksperimen ini, pemerintah Brazil menyetujui pembentukan ribuan lingkaran budaya di seluruh negeri. Tahun 1964-1969, sebuah kudeta militer mengakhiri upaya itu dan Paulo Freire di penjara selama 70 hari karena dianggap sebagai penghianat. Setelah pengasingan Paulo Freire kemudian menjadi guru besar di Fakultas Ilmu Pendidikan Universitas Harvard, Paulo Freire juga pernah menjabat sebagai 
penasehat ahli kantor pendidikan dewan Gereja sedunia di Jenewa. Pada tahun 1979, Paulo Freire kembali ke Brazil dan pindah kembali pada tahun 1980. Paulo Freire bergabung dengan Partai Pekerja di kota Sao Paulo, dan bertindak sebagai pengawas untuk proyek keaksaraan orang dewasa tahun 19801986. Ketika Partai Pekerja menang dalam Pemilukota Praja pada tahun 1988, Paulo Freire diangkat menjadi Sekretaris Pendidikan untuk Sao Paulo. Freire meninggal dunia di Rumah Sakit Albert Einstein, Sao Paulo Brazil, genap dalam usia 75 tahun akibat gagal jantung pada tanggal 2 Mei 1997 di Sao Paulo.

Tabel 1 Studi Komperatif Konsep Pendidikan Tjokroaminoto, KI Hadjar dan Freire

\begin{tabular}{|c|c|c|c|c|}
\hline Nama & Tjokroaminoto & Ki Hadjar & Paulo Freire & Sisdiknas \\
\hline Kesamaan & \multicolumn{4}{|c|}{$\begin{array}{l}\text {-Konsep pendidikan dalam pemikiran Tjokroaminoto, Ki Hadjar, Freire dan Sisdiknas memiliki } \\
\text { kesamaan dalam hasil yang ingin dicapai yaitu kepribadian peserta didik. Secara garis besar } \\
\text { pendidikan menurut Tjokroaminoto, Ki Hadjar, Freire dan Sisdiknas adalah prsoes } \\
\text { pengkwalitasan individu peserta didik. Selain itu pendidikan merupakan alat untuk } \\
\text { menyelamatkan manusia dari kemiskinan intelektual dan ekonomi. } \\
\text {-Pendidikan yang digagas oleh Tjokroaminoto, Ki Hadjar, Freire dan Sisdiknas dalam sejarah } \\
\text { kemunculannya memiliki kesamaan yaitu berdasarkan hasil refleksi situasi dan kondisi sosial } \\
\text { yang ada. Pendidikan dalam konsep pemikiran Tjokroaminoto, Ki Hadjar dan Freire lahir atas } \\
\text { dasar situasi ekonomi politik Negara sedang dikuasai oleh kekuatan imperialisme. Sedangkan, } \\
\text { Sisdiknas tahun } 2003 \text { merupakan hasil dari perjuangan mahasiswa Tahun 1998, dan } \\
\text { perjuangan forum rektor yang bertempat di Bandung pasca kemerdekaan. }\end{array}$} \\
\hline Perbedaan & $\begin{array}{l}\text {-Tjokroaminoto } \\
\text { menegaskan pendidikan } \\
\text { tidak cukup dengan } \\
\text { pengkwalitasan ilmu } \\
\text { pengetahuan umum saja. } \\
\text { Namun ada hal yang } \\
\text { perlu diperhatikan secara } \\
\text { kritis dalam pendidikan, } \\
\text { harus ada keseimbangan } \\
\text { ilmu umum dengan ilmu } \\
\text { agama. }\end{array}$ & \begin{tabular}{|lrl}
-Konsep & pendidikan & Ki \\
Hadjar & \multicolumn{3}{l}{ yang } \\
membedakann-ya \\
dengan & Tjokroaminoto, \\
serta & Freire & dan \\
Sisdiknas, & menurutnya \\
pendidikan & adalah \\
proses & pemberian nilai- \\
nilai & luhur & kepada \\
semua & & peserta \\
didik/siswa. &
\end{tabular} & $\begin{array}{l}\text { Pendidikan menurut } \\
\text { Freire sangat } \\
\text { politis, sehingga } \\
\text { tidak heran } \\
\text { pandangannya } \\
\text { menuai pro kontra } \\
\text { dalam masyarakat. } \\
\text { Pandang Freire } \\
\text { yang paling kritis } \\
\text { dalam pendidikan, } \\
\text { menurutnya } \\
\text { pendidikan } \\
\text { merupakan ajang } \\
\text { pertarungan } \\
\text { ideologi. }\end{array}$ & $\begin{array}{lr}\text { Pendidikan } & \text { yang } \\
\text { ditekan } & \text { oleh } \\
\text { Sisdiknas } & \text { lebih } \\
\text { universal } & \text { yaitu } \\
\text { pendidikan } & \text { harus } \\
\text { mencapai aspek } & \text { kognitif, afektif } \\
\text { dan psikomorik. } & \\
\text { Sisdiknas r } & \\
\text { mengasumsi } 3 \\
\text { point tersebut } \\
\text { yang harus } \\
\text { menjadi landasan } \\
\text { dalam ram sistem } \\
\text { pendidikan } \\
\text { Indonesia. }\end{array}$ \\
\hline
\end{tabular}

Berdasarkan tabel di atas, menurut pandangan penulis masih banyak hal yang perlu dikritisi atas pandangan Tjokroaminoto, Ki Hadjar, Freire dan Sisdiknas. Jaman semakin berubah, proses pembelajaran yang semakin canggih, dan akses informasi semakin gampang, 
harus menjadi bahan pertimbangan oleh pakar-pakar pendidikan ketika merumuskan satu konsep pendidikan baru. Hal yang perlu menjadi catatan adalah teori sosial harus selalu disesuaikan dengan situasi dan kondisi yang sedang berkembang.

Pendidikan yang digambarkan Tjokroaminoto dan Ki Hadjar pada masa bumi nusantara berada di bawah penjajahan imperialisme Belanda. Sedangkan konsep pendidikan yang dipraktekan Freire di Brazil pada abad ke-20, dimana situasi ekonomi politik sedang dilanda krisis dan berimbas pada kondisi sosial masyarakat. Hal itu yang membuat Freire mendesain pendidikan sangat politis. Bagi Freire pendidikan merupakan ajang pertarungan ideologi antara kelas penguasa dengan dan rakyat tertindas. Sedangkan kemunculan Sisdiknas merupakan dari hasil sistem pendidikan pasca kemerdekaan.

Dalam pandangan penulis pendidikan itu harus berpihak, proses pembelajaran yang diberikan oleh pendidik harus sesuai dengan kebutuhan peserta didik. Kelemahan pemerintah pada sektor pendidikan sekarang adalah selalu mengotak atik kurikulum tanpa melihat apa yang menjadi persolan pada akar rumput. Hal yang menjadi pemicu perubahan kurikulum bukan karena kebutuhan peserta didik dan bukan pula atas rekomendasi pendidik secara nasional, melainkan karena pendidikan sudah dipolitisasi pemerintah. Setiap pergantian kepala Negara dan menteri pendidikan, kebijakan pendidikanpun pasti ikut berubah. Kondisi seperti ini yang membuat pendidikan nasional belum mampu bersaing dengan sistem pendidikan di Negara-negara lain.

Sedangkan tujuan pendidikan selain untuk menyelamatkan umat manusia dari kemiskinan intelektual, ekonomi dan mengangkat harkat martabat seseorang, besar harapan agar pendidikan mampu menciptakan manusia-manusia kritis dan peka terhadap persoalan sosial. Minimnya partisipasi masyarakat terhadap pendidikan, bukan karena kesadaran mereka yang masih terbelakang. Melainkan pendidikan yang semakin mahal dan lemahnya kontribusi Negara dan pemerintah setempat, membuat masyarakat di seluruh pelosok negeri belum merata dalam mengakses pendidikan yang layak.

\section{SIMPULAN DAN SARAN}

A. Simpulan

Pendididikan merupakan usaha sadar yang dilakukan oleh semua umat manusia untuk mengembangkan potensi dalam dirinya masing-masing. Selain untuk mengembangkan potensi peserta didik, pendidikan adalah alat untuk memajukan peradaban bangsa dan Negara. Sejarah revolusi industri di Inggris, abad ke-18 ditemukanya gilda-gilda (alat poduksi) 
merupakan suatu bentuk hasil dari produk ilmu pengetahuan/pendidikan dan perkembangan filsafat Eropa.

Pendidikan dalam pemikiran Tjokroaminoto, Ki Hadjar, Paulo Freire dengan Sisdiknas memiliki kesamaan dalam hasil yang ingin dicapai yaitu kepribadian peserta didik. Secara garis besar konsep pendidikan menurut Tjokroaminoto, Ki Hadjar, Paulo Freire dengan Sisdiknas merupakan upaya mengembangkan potensi peserta didik dan sebagai alat untuk mengangkat harkat dan martabat seseorang agar terbebas dari belenggu kebodohan.

Hal yang membuat pendidikan mengalami disorientasi adalah dimana masyarakat menganggap orientasi pendidikan hanya untuk bersaing pada dunia kerja. Dengan tergabungnya Indonesia dalam Masyarakat Ekonomi Asean (MEA) ditetapkan Januari 2016 lalu, semakin mengaburkan esensi pendidikan. Salah satu efek dari disahkannya kebijakan MEA dalam dunia pendidikan adalah terjadinya liberalisasi pendidikan dan menciptkan generasi-generasi yang siap kerja serta mampu bertarung dalam ranah pasar bebas. Padahal sudah sangat jelas bahwa tujuan pendidikan tidak hanya sebatas untuk bersaing pada dunia kerja, melainkan pendidikan harus mampu menjawab persoalan ekonomi, politik, sosial dan budaya.

Berdasarkan amanat pembukaan UUD Tahun 1945 bahwa pemeritah Republik Indonesia harus melindungi segenap bangsa Indonesia, dan seluruh tumpah darah Indonesia, dan memajukan kesejahteraan rakyat, mencerdaskan kehidupan bangsa, serta Negara Indonesia harus ikut serta dalam melaksanakan ketertiban dunia. Tujuannya agar rakyat Indonesia kelak menjadi Negara yang sejahtera secara ekonomi, demokrasi secara politik, adil secara sosial dan partisipatif secara budaya. Untuk menjawab semua itu tidak lain sebagai solusi alternatif dengan memberikan fasilitas pendidikan terhadap semua rakyat Indonesia, sebagaimana ditegaskan dalam pasal 31 (1-2).

Undang-Undang Dasar Tahun 1945, pasal 31 (4) Pemerintah memprioritaskan anggaran pendidikan sekurang-kurangnya 20\% dari Anggaran Pendapatan dan Belanja Negara serta dari Anggaran Pendapatan Belanja Daerah untuk memenuhi kebutuhan penyelenggaraan pendidikan nasional. Berdasarkan data BPS, Anggaran Belanja Negara Tahun 2016 yang dialokasikan untuk pendidikan sebesar 424 Triliun. Namun yang menjadi evaluasinya anggaran tersebut sampai sekarang belum berjalan maksimal. Hal itu dibuktikan masih adanya perbedaan partisipasi pendidikan antara di Desa dan di Kota.

Esensi sejatinya pendidikan yaitu membentuk pola pikir yang kritis kepada semua peserta didik, agar menjadi manusia yang berguna bagi diri sendiri, orang lain, serta bangsa dan Negara. Sedangkan, Pendidikan yang membebaskan merupakan pendidikan yang diberikan 
kepada peserta didik sesuai dengan perkembangan dan potensi yang dimiliki oleh peserta didik agar tumbuh berkembang menjadi manusia yang merdeka.

B. Saran

Delapan belas Tahun sudah Indonesia berada di bawah sistem Reformasi, kwalitas pendidikan nasional masih tergolong rendah jika dibandingkan dengan kwalitas pendidikan luar negeri. Dalam penelitian Organisation for Economic Cooperation and Development Tahun 2015 (organisasi internasional yang menganut pasar bebas), dari 76 Negara yang disurvei kualitas pendidikan Indonesia masuk pada urutan ke-69. Hal itu dikarenakan masih lemahnya peran Negara dalam megawas perkembangan pendidikan.

Lemahnya peran masyarakyat, untuk melakukan pengontrolan terhadap kebijakankebijakan pendidikan yang cenderung tidak memihak terhadap rakyat, dan lembaga yang berwenang harus mengkaji ulang isian UU Sidiknas pasal 49 (2) tentang alokasi anggaran pendidikan yang belum merata secara nasional. Serta Negara harus menjalankan amanat UUD 1945 pasal 31 (4) atas pembiayaan pendidikan.

Keterbatasan kemampuan penyusun dalam meneliti konsep pendidikan dalam pemikiran Tjokroaminoto, Ki Hadjar, Paulo Freire dan Sisdiknas, harapannya dapat diperdalam oleh peneliti berikutnya. Tema yang dipaparkan oleh penyusun mungkin terlalu luas, sehingga perlu juga memfokuskan pada salah satu tokoh agar lebih mendalam.

\section{DAFATAR PUSTAKA}

Ahmad Sanusi, 1936. Perjuangan Melawan Penjajah. Jakarta: Balai Pustaka.

Ahmad Syafi'I Maarif, 1996. Islam dan Masalah Kenegaraan. Jakarta: Pustaka LP3ES Indonesia.

Arminda S. Alisjahbana, 2000. Otonomi Daerah dan Desentaralisasi Pendidikan. Bandung: Universitas Padjajaran.

Darsiti Soeratman, 1989. Kehidupan Dunia Kraton Surakarta. Yogyakarta: Disertasi Pascasarjana UGM.

Darsiti Soeratman, 1985. Biografi Ki Hadjar Dewantara. Jakarta: Depdikbud.

Gonggong, 1985. HOS. Tjokroaminoto. Jakarta: Depdikbud Proyek Pendidikan Sejarah Perjuangan Bangsa.

George D. Larson, 1990. Masa Menjelang Revolusi. Yogyakarta: Gamapress. 
HOS Tjokroaminoto, 2015. Pelopor Pejuang, Guru Bangsa dan Penggerak Sarikat Islam. Yogyakarta: Ilmu Giri.

H.A.R. Tillar, 2004. Paradigma Baru Pendidikan Nasional. Jakarta: Rineka Cipta.

Mita Yuniati, 2015. Dampak MEA Terhadap Pendidikan Indonesia.Nasional: Islampos

Kehidupan dan Karya Paulo Freire, 2002. Yogyakarta: Pustaka Pelajar Kerjasama Dengan Komunitas APIRU Yogyakarta.

Ki Hadjar Dewantara, 2015. Sang Guru, Haidar Musyafa. Yogyakarta: Imania.

Ki Hadjar Dewantara, 1951. Pengaruh Keluarga Terhadap Moral. Jakarta: Endang.

Manshuri 1976. Taman Siswa Merombak Sistem Pendidikan Kolonial. Yogyakarta: MLPTS.

Majelis Luhur Persatuan Taman Siswa. 1976. Pendidikan dan Pembagunan $\quad$ Yogyakarta: MLPTS.

Muh. Hanif Dhiri, 2002. Islam dan Pembebasan. Jakarta: Djambatan dan Penerbit Pena

Paulo Freire, 2008. Pendidikan Kaum Tertindas. Jakarta: Pustaka LP3ES.

Paulo Freire, 1984. Pendidikan Sebagai Praktek Pemebebasan. Jakarta: Gramedia.

Paulo Freire, 2000. Pendidikan Sebagai Proses. Yogyakarta: Pustaka Pelajar.

Santi Dwikartika, 2013. Otonomi Pendidikan Bagi Perguruan Tinggi. Jakarta: Direktorat Pendidikan Tinggi.

Undang-Undang Dasar Tahun 1945, 2009. Yogyakarta: Pustaka Yustisia.

Undang-Undang Sisdiknas No.20 Tahun 2003, 2011. Yogyakart: Pustaka Pelajar.

Undang-Undang Pendidikan Tinggi No.12 Tahun 2012, File Permendikbud. 